\title{
Availability and Clinical Use of Different In-Shoe Devices for Partial Weight Bearing - A Systematic Review
}

1 Petra Josipović

1 Medical Faculty in Ljubljana

Fizio Tech d.o.o, Croatia patients to comply with weight-bearing limitations. With additional randomised controlled trials, biofeedback devices may very well become a part of the mainstay of clinical practice in orthopaedic partial weightbearing patients.

\section{Abstract

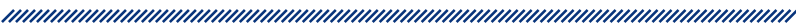

Introduction: Physiotherapists use different methods such as tactile feedback, scales and biofeedback to teach patients applying the partial weight bearing instructions. Biofeedback systems are more effective and objective method than usage of conventional bathroom scales in training patients to comply with weightbearing limitations.

Aim: The current review will focus on the availability and clinical use of biofeedback in-shoe device in patients with prescribed PWB.

Methods: A literature search was performed using the following keywords: partial weight bearing, biofeedback in-shoe device and surgery. Five databases were searched appropriate for screening (PubMed, PEDro, Google Scholar, Clinicaltrials.gov and ScienceDirect).

Results: Filtration strategy was used in a literature search. 15 sources were selected for final analysis. Qualitative analytical approach was used in data processing. Conclusion: Biofeedback systems have been more effective than conventional bathroom scales in training
Keywords: Weight bearing, partial pressure, feedback sensory, foot orthoses, rehabilitation

Article received: 19.02.2020.

Article accepted: 01.07.2020.

https://doi.org/10.24141/1/6/2/8

Corresponding author:

Petra Josipović

A: Jelušićev prilaz 2, Pula

E-mail: petraa.josipovic @gmail.com

T: +385995921414 


\section{Introduction}

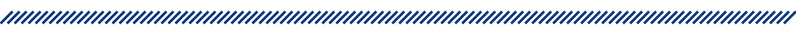

Partial weight bearing (PWB) is a common intervention in rehabilitation process of orthopaedic patients and patients who had certain lower-body injuries. ${ }^{1}$ PWB is defined as a particular amount of patient's weight during standing and walking, when using assistive device. ${ }^{2}$ the purpose of PWB is that limiting the amount of body weight during rehabilitation will enable better ingrowth of prosthesis or prevent dislocation and promote healing in fracture care. ${ }^{3}$ PWB is prescribed by the treating surgeon or physiotherapist and starts on the first day after surgical procedure with low weight bearing on the affected limb and increases until full weight bearing is accomplished. ${ }^{4,5}$ Physiotherapist prescribes the maximum kgs or \% of weight bearing. ${ }^{6}$ By partial weight bearing, $20-50 \%$ of the body weight is tolerated. ${ }^{7}$

Physiotherapists use different methods such as tactile feedback, scales and biofeedback to teach patients applying the partial weight bearing instructions. ${ }^{8}$ The most common method is use of scale. ${ }^{8}$ The difficulty in transferring the static measurement of scales to the dynamic activity in gait has limited the use of scales in partial weight-bearing training. ${ }^{8,9}$ Biofeedback systems are more effective and objective method than usage of conventional bathroom scales in training patients to comply with weight-bearing limitations. ${ }^{10}$

New technological advances have provided commercially available biofeedback systems that are fully portable such as Smartstep (Andante Medical Devices Ltd, Beer Sheva, Israel) and Sensistep (Evalan, Netherlands), Pedar (Novelgmbh, Munich, Germany) and F-Scan (Tekscan Inc., Boston, MA, USA). The SmartStep insole measures the force applied under the heel and forefoot of the affected limb. The data is received and analysed by the miniature portable control unit, which is worn around the ankle. ${ }^{12}$ SensiStep uses a force sensor that is placed inside a special sandal. This sensor registers how much axial force is exercised on the leg and sends data wirelessly via Bluetooth and WiFi. This provides information about the intensity of movement and the amount of weight on the leg. ${ }^{13} \mathrm{~F}$-scan and Pedar are available for researches and clinical use and have good accuracy and validity. ${ }^{14,15}$ The Pedar system is one of the most commonly used systems for in-shoe pressure measurement. The Pedar in-shoe system is an insole with 99 capacitive sensors. The system works with Bluetooth wireless telemetry system in a wide range. The system connects to highly conforming, elastic sensor insoles that cover the entire plantar surface of the foot (Novel). ${ }^{15}$ The OpenGo science system (Moticon, Munich, Germany) incorporates 12 capacitive sensors, a 3D accelerometer and a temperature sensor, measuring peak pressures, pressure distribution, acceleration, motion sequences, gait patterns and temperatures. It operates wireless and the data is stored on a flash drive. The insole can be placed in any shoe and the system has an automated zeroing system so the shoes can be changed at random. ${ }^{16}$ OpenGo has shown a good correlation between the insole and the force plate system for temporospatial. A study showed that the system could be used in broad clinical trials that require step by step or gait analysis over a long period of time. ${ }^{16}$ The F-scan mobile system is a commercial in-shoe force/pressure measurement system. The in-shoe system has been used in clinical studies focused mainly on the evaluation of various therapeutic measurements. ${ }^{17}$ The system uses ultra-thin in-shoe sensors and provides pressure information intended for gait analysis. Another advantage is that the system utilizes relatively low-cost sensors and pressure data is stored in a data-logger, so the subject can move freely. ${ }^{17}$ The insole consists of two polyester sheets whose inner surfaces are printed with electrical circuits. The insole consists of 860 individual pressure-sensing locations, which leads to a sensor density of 4 per $\mathrm{cm} 2 .{ }^{18}$ The total mass of all external devices is approximately $1.8 \mathrm{~kg}$. This includes two inshoe sensors, two receiver units attached to the subject's lower leg, one data-logger unit attached at the waist level and several connection cables. ${ }^{17,18}$ Different studies show that the system not only responds to the applied pressure, but also can be influenced by other variables, such as surface contact hardness conditions, creeping and temperature. ${ }^{18,19}$ Comparative studies found out that Fscan had higher average errors, but a lower repeatability for contact area, especially at lower pressures. This is due to an interaction between the inherent noise in the resistive system and the larger number of sensors. ${ }^{19-24}$ Orpyx LogR (Orpyx Inc., Calgary, Canada) is a solution designed for the accurate, real-time measurement of foot and plantar pressure analysis. The system uses eight SSR sensors, it is less expensive but available only on limited basis. ${ }^{24}$

Although many studies have been undertaken to compare and validate the commercially available biofeedback systems in gait analysis, running analysis $2,3,6,11,14,21,23,24$ there is as still lack of information on randomized clinical trials which examine clinical and outpatient activity use of biofeedback in-shoe devices in patients with prescribed PWB. .,5,- $-9,15-19,22-24^{-24}$ 
The current review will focus on the availability and clinical use of biofeedback in-shoe device in patients with prescribed PWB.

\section{Materials and Methods}

A literature search was performed using the following keywords: partial weight bearing, biofeedback in-shoe device and surgery. Five databases were searched appropriate for screening (PubMed, PEDro, Google Scholar, Clinicaltrials.gov and ScienceDirect).

A literature search performed in PubMed database using the keywords partial weight bearing and biofeedback device, resulted with the number of 15 sources. Furthermore, the strategy of filtration is used regarding to the article types, text availability and publication dates. Only clinical trials, not older than 10 years with full text availability were searched. Advance search resulted with 3 sources which were included in final analysis.

The simple literature search performed in Physiotherapy Evidence Database (PEDro) using terms partial weight bearing, biofeedback device and in-shoe device, resulted with the number of 26 sources. Regarding to research question and topic, 1 source was selected for final analysis.

A literature search performed in Google Scholar database using terms partial weight bearing and feedback device resulted with 116000 sources. Filtration strategy was used to eliminate sources which did not met criteria. Elimination criteria was; articles older than 5 years and keywords (partial weight bearing and feedback device) not occurring in the title of article. 38 articles met criteria. Regarding to research question and topic, 6 sources were selected for final analysis.

The simple literature search performed in Clinicaltrials. gov database using terms surgery, biofeedback device and in-shoe device, resulted with the number of 4 sources. Regarding to research question and topic, 1 source was selected for final analysis.

Furthermore, the advance literature search performed in ScienceDirect database using terms biofeedback device in partial weight bearing, resulted with the number of 25 sources. Only clinical trials, not older than 10 years were included in search. Regarding to research question and topic, 4 sources were selected for final analysis.

Results of literature search performed in listed databases are shown in Table 1.

\begin{tabular}{|c|c|c|}
\hline Database & Keywords & $\begin{array}{l}\text { Number } \\
\text { of sources } \\
\text { selected } \\
\text { for final } \\
\text { analysis }\end{array}$ \\
\hline PubMed & $\begin{array}{c}\text { Partial weight bearing, } \\
\text { biofeedback in-shoe } \\
\text { device }\end{array}$ & 3 \\
\hline PEDro & $\begin{array}{c}\text { partial weight bearing, } \\
\text { biofeedback device, in- } \\
\text { shoe device }\end{array}$ & 1 \\
\hline Google Scholar & $\begin{array}{l}\text { partial weight bearing } \\
\text { and feedback device }\end{array}$ & 6 \\
\hline Clinicaltrials.gov & $\begin{array}{l}\text { Surgery, biofeedback } \\
\text { device, in-shoe device }\end{array}$ & 1 \\
\hline ScienceDirect & $\begin{array}{l}\text { Biofeedback device, } \\
\text { partial weight bearing }\end{array}$ & 4 \\
\hline
\end{tabular}

Overall number of sources selected for final analysis was 15. Qualitative analytical approach was used in data processing.

\section{Results}



The flow of information through the different phases of a systematic review are shown in PRISMA flow diagram Figure 1.

The summary of included records is presented in Table 2 . 


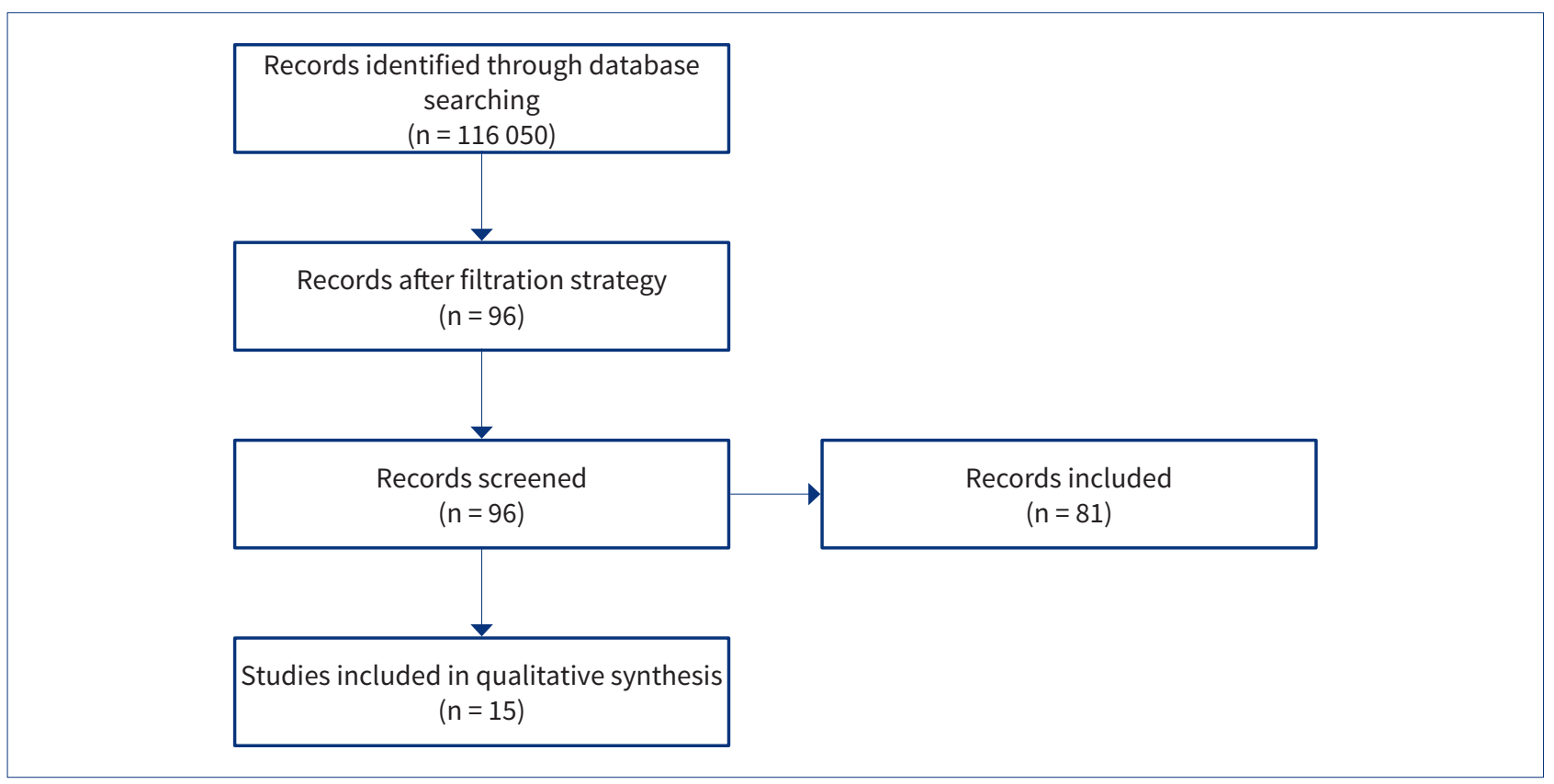

Figure 1. PRISMA flow diagram

\begin{tabular}{|c|c|c|c|c|c|}
\hline Trial & State & Design & Participants & Intervention & Results \\
\hline $\begin{array}{l}\text { Hurkmans HL, } \\
\text { Bussmann } \\
\text { JB, Benda } \\
\text { E, Verhar JA, } \\
\text { Stam HJ. }{ }^{25}\end{array}$ & $\begin{array}{l}\text { The } \\
\text { Netherlands }\end{array}$ & $\mathrm{RCT}$ & $\begin{array}{l}\text { Patients }(\mathrm{N}=38) \text { after } \\
\text { THA with trochanteric } \\
\text { osteotomy. }\end{array}$ & $\begin{array}{l}\text { Patients were trained } \\
\text { with }(n=18) \text { or without } \\
\text { ( } n=20) \text { audio feedback } \\
\text { to perform PWB at a } \\
10 \% \text { body weight (BW) } \\
\text { target load. }\end{array}$ & $\begin{array}{l}\text { PWB training with } \\
\text { audio feedback } \\
\text { resulted in better PWB } \\
\text { (11.1\% BW vs control, } \\
21.9 \% \text { BW; } P=.006)\end{array}$ \\
\hline $\begin{array}{c}\text { Gray FB, Gray } \\
\text { C, McClanahan } \\
\text { J. }{ }^{26}\end{array}$ & USA & RCT & $\begin{array}{l}\text { Three groups of } \\
\text { healthy volunteers } \\
\text { were instructed to } \\
\text { bear } 60 \text { pounds of } \\
\text { weight on a foot in } \\
\text { one of three ways: } \\
\text { on a bathroom scale, } \\
\text { against a therapist's } \\
\text { hand, or on a force- } \\
\text { monitoring platform. }\end{array}$ & $\begin{array}{l}\text { A force-monitoring } \\
\text { in-shoe device was } \\
\text { used to ascertain } \\
\text { accuracy in following } \\
\text { instructions } \\
\text { concerning partial } \\
\text { weight bearing. }\end{array}$ & $\begin{array}{l}\text { The significantly } \\
\text { greater accuracy was } \\
\text { found in the group } \\
\text { instructed on the } \\
\text { force-monitoring } \\
\text { platform. }\end{array}$ \\
\hline $\begin{array}{l}\text { Hershko E, } \\
\text { Tauber C, } \\
\text { Carmeli E. }{ }^{27}\end{array}$ & Israel & RCT & $\begin{array}{l}\text { After orthopaedic } \\
\text { surgery, } 33 \text { patients, } \\
\text { randomly divided into } \\
\text { a study group ( } n=15) \\
\text { and a control group ( } n \\
=18) .\end{array}$ & $\begin{array}{c}\text { SmartStep Gait System } \\
\text { was used in study } \\
\text { group. }\end{array}$ & $\begin{array}{l}\text { A significant difference } \\
(P<.05) \text { was found } \\
\text { between the groups. } \\
\text { Study subjects were } \\
\text { able to follow weight- } \\
\text { bearing instructions } \\
\text { better. }\end{array}$ \\
\hline
\end{tabular}




\begin{tabular}{|c|c|c|c|c|c|}
\hline Trial & State & Design & Participants & Intervention & Results \\
\hline Isakov E. ${ }^{28}$ & Israel & Q-RCT & $\begin{array}{l}\text { Study group ( } \mathrm{n}=24) \\
\text { used Biofeedback } \\
\text { device (insole) and } \\
\text { control group }(\mathrm{n}=18) \\
\text { used force plate to } \\
\text { establish effectiveness, } \\
\text { validity of Smartstep } \\
\text { and to compare it with } \\
\text { force plate. }\end{array}$ & $\begin{array}{l}\text { SmartStep system was } \\
\text { used in study group for } \\
\text { measuring the amount } \\
\text { of weight in the } \\
\text { affected limb and for } \\
\text { biofeedback training. }\end{array}$ & $\begin{array}{l}\text { The SmartStep could } \\
\text { repeat the same } \\
\text { results with } 0.53 \\
\text { kg error of mean. } \\
\text { Significant correlation } \\
\text { was found between } \\
\text { results obtained from } \\
\text { SmartStep and force } \\
\text { plate. Smartstep } \\
\text { significantly improved } \\
\text { patients PWB. }\end{array}$ \\
\hline $\begin{array}{l}\text { Lieshout R, } \\
\text { Pisters M, } \\
\text { Vanwanseele } \\
\text { B, Bie RB, } \\
\text { Wouters E.J, } \\
\text { Stukstette } \\
\text { JM. }{ }^{29}\end{array}$ & Netherlands & $\begin{array}{l}\text { Convergent } \\
\text { mixed- } \\
\text { methods } \\
\text { design }\end{array}$ & $\begin{array}{l}\text { Nine pairs of physical } \\
\text { therapists and their } \\
\text { patients participated. }\end{array}$ & $\begin{array}{l}\text { Patients prescribed } \\
\text { with partial weight } \\
\text { bearing and their } \\
\text { physical therapists } \\
\text { were asked to use } \\
\text { SmartStep and } \\
\text { OpenGo-Science } \\
\text { biofeedback devices } \\
\text { during supervised } \\
\text { rehabilitation. }\end{array}$ & $\begin{array}{l}\text { The overall } \\
\text { usability from both } \\
\text { perspectives seemed } \\
\text { to be acceptable for } \\
\text { OpenGo-Science. For } \\
\text { SmartStep, overall } \\
\text { usability seemed only } \\
\text { acceptable from the } \\
\text { patient's perspective. }\end{array}$ \\
\hline $\begin{array}{l}\text { Döbele S, } \\
\text { Deininger C, } \\
\text { Sandmann } \\
\text { GH, Schmitt } \\
\text { A, Freude T, } \\
\text { Stöckle U, } \\
\text { Lucke M. }{ }^{30}\end{array}$ & Czechoslovakia & $\begin{array}{l}\text { Feasibility } \\
\text { study }\end{array}$ & $\begin{array}{c}20 \text { young, healthy } \\
\text { subjects completed a } \\
\text { course of } 500 \mathrm{~m} \text { that } \\
\text { contained several } \\
\text { stairs, with a PWB of } \\
15 \mathrm{~kg}\end{array}$ & $\begin{array}{l}\text { During the entire test, } \\
\text { the axial load, the } \\
\text { acceleration and the } \\
\text { temperature were } \\
\text { measured with a novel } \\
\text { insole sensor system. }\end{array}$ & $\begin{array}{l}\text { The presented sensor } \\
\text { sole might be a useful } \\
\text { tool to obtain more } \\
\text { precise insight of } \\
\text { outpatients' activity } \\
\text { and load to the injured } \\
\text { limb during the } \\
\text { healing process. }\end{array}$ \\
\hline $\begin{array}{l}\text { Van Lieshout } \\
\text { R, Stukstette } \\
\text { MJ, De Bie RA, } \\
\text { Vanwanseele } \\
\text { B, Pisters MF. }{ }^{31}\end{array}$ & $\begin{array}{l}\text { The } \\
\text { Netherlands }\end{array}$ & $\begin{array}{l}\text { Controlled } \\
\text { laboratory } \\
\text { study to assess } \\
\text { criterion- } \\
\text { related } \\
\text { validity, with a } \\
\text { cross-sectional } \\
\text { within- } \\
\text { subject design. }\end{array}$ & $\begin{array}{l}\text { Fifty-five healthy } \\
\text { adults participated in } \\
\text { validity of biofeedback } \\
\text { in-shoe device. }\end{array}$ & $\begin{array}{l}\text { Usage of biofeedback } \\
\text { devices under } 3 \\
\text { different weight } \\
\text { bearing conditions. } \\
\text { OpenGo science, } \\
\text { SmartStep, and } \\
\text { SensiStep) was } \\
\text { assessed. }\end{array}$ & $\begin{array}{l}\text { The } \\
\text { OpenGo science and } \\
\text { SmartStep provided } \\
\text { valid feedback in the } \\
\text { lower weight-bearing } \\
\text { categories, and the } \\
\text { SensiStep showed } \\
\text { poor validity of } \\
\text { feedback in all weight- } \\
\text { bearing categories. }\end{array}$ \\
\hline $\begin{array}{l}\text { Tkachenko-Bril } \\
\text { A, Jagos H, } \\
\text { David V, Pils K, } \\
\text { Gaudernak J, } \\
\text { Rafolt D. }{ }^{32}\end{array}$ & Austria & $\begin{array}{l}\text { Proof of } \\
\text { concept }\end{array}$ & $\begin{array}{l}\text { One patient after a hip } \\
\text { fracture. }\end{array}$ & $\begin{array}{l}\text { A real-time feedback } \\
\text { system based on } \\
\text { eSHOE instrumented } \\
\text { insoles was tested in } \\
\text { order to preliminarily } \\
\text { quantify its efficiency } \\
\text { at improving geriatric } \\
\text { patients' compliance. }\end{array}$ & $\begin{array}{l}\text { Preliminary results } \\
\text { of one patient show } \\
\text { that number of } \\
\text { correctly loaded steps } \\
\text { was nearly doubled. } \\
\text { The system has a } \\
\text { positive effect on } \\
\text { PWB performance of } \\
\text { geriatric subjects while } \\
\text { walking. }\end{array}$ \\
\hline
\end{tabular}




\begin{tabular}{|c|c|c|c|c|c|}
\hline Trial & State & Design & Participants & Intervention & Results \\
\hline $\begin{array}{c}\text { Zhang DT, } \\
\text { Goral DC, } \\
\text { Fragomen AT, } \\
\text { Rozbruch SR. }{ }^{33}\end{array}$ & USA & Cohort design & $\begin{array}{l}\text { Patients who had } \\
\text { PWB restrictions after } \\
\text { orthopedic surgery } \\
(n=21) .\end{array}$ & $\begin{array}{c}\text { A customized thin } \\
\text { film sensory insole } \\
\text { Soleforce was } \\
\text { developed and tested } \\
\text { in orthopedic patients } \\
\text { with PWB. }\end{array}$ & $\begin{array}{l}\text { The average precision } \\
\text { value for the patients } \\
\text { improved from } 1.31 \\
\text { (range } 0.23-2.00 \text { ) } \\
\text { before Soleforce }{ }^{\circledR} \\
\text { feedback to } 1.09 \text { (0.84- } \\
\text { 1.70) after feedback. } \\
\text { Using the Soleforce }{ }^{\circledR} \\
\text { leads to improved } \\
\text { precision for adhering } \\
\text { to weightbearing } \\
\text { restrictions. }\end{array}$ \\
\hline Le AY. ${ }^{34}$ & USA & $\mathrm{RCT}$ & $\begin{array}{l}10 \text { healthy participants } \\
\text { were trained to } \\
\text { partially weight bear } \\
25 \% \text { of their body } \\
\text { weight on one leg. }\end{array}$ & $\begin{array}{c}\text { Group } 1 \text { walked } \\
50 \text { steps without } \\
\text { feedback, followed by } \\
50 \text { steps with real-time } \\
\text { feedback. The other } \\
\text { five subjects (Group 2) } \\
\text { walked } 50 \text { steps with } \\
\text { feedback, followed } \\
\text { by } 50 \text { steps without } \\
\text { feedback. }\end{array}$ & $\begin{array}{l}\text { A significant statistical } \\
\text { difference between } \\
\text { the steps with and } \\
\text { without feedback was } \\
\text { found ( } P=0.0165) \text {. This } \\
\text { indicates feedback } \\
\text { significantly affected } \\
\text { the subject's ability to } \\
\text { partially weight bear } \\
\text { within the target load } \\
\text { range. }\end{array}$ \\
\hline $\begin{array}{c}\text { Saito M, } \\
\text { Nakajima K, } \\
\text { Takano C, Ohta } \\
\text { Y, Sugimoto C, } \\
\text { Ezoe R. }{ }^{35}\end{array}$ & Japan & $\begin{array}{l}\text { Experimental } \\
\text { study }\end{array}$ & $\begin{array}{l}\text { One healthy young } \\
\text { participant and two } \\
\text { elderly participants. }\end{array}$ & $\begin{array}{l}\text { Participants wore } \\
\text { prototype of in-shoe } \\
\text { device and performed } \\
\text { a level, straight } \\
\text { walking trial. }\end{array}$ & $\begin{array}{c}\text { The device was } \\
\text { confirmed to provide a } \\
\text { quantitative estimate } \\
\text { of human plantar } \\
\text { pressure. }\end{array}$ \\
\hline Morris SJ. ${ }^{36}$ & USA & $\begin{array}{l}\text { Feasibility } \\
\text { study }\end{array}$ & $\begin{array}{l}\text { Subject testing of the } \\
\text { GaitShoe was carried } \\
\text { out on ten healthy } \\
\text { subjects with normal } \\
\text { gait and five subjects } \\
\text { with Parkinson's } \\
\text { disease. }\end{array}$ & $\begin{array}{c}\text { Gait analysis with } \\
\text { GaitShoe. }\end{array}$ & $\begin{array}{l}\text { GaitShoe proved } \\
\text { highly capable of } \\
\text { detecting heel strike } \\
\text { and toe off, as well as } \\
\text { estimating orientation } \\
\text { and position of the } \\
\text { subject. }\end{array}$ \\
\hline $\begin{array}{c}\text { Raaben M, } \\
\text { Vogely HC, } \\
\text { Blokhuis TJ. }{ }^{37}\end{array}$ & Netherlands & Pilot RCT & $\begin{array}{l}24 \text { participants who } \\
\text { underwent THA were } \\
\text { randomized to either } \\
\text { the control or the } \\
\text { intervention group. }\end{array}$ & $\begin{array}{l}\text { The intervention group } \\
\text { received real-time, } \\
\text { visual biofeedback } \\
\text { on weight-bearing } \\
\text { during training with } \\
\text { the physical therapist } \\
\text { during hospitalization } \\
\text { and at twelve weeks } \\
\text { follow up. }\end{array}$ & $\begin{array}{l}\text { Significant } \\
\text { improvement in peak } \\
\text { load and reduced } \\
\text { use of walking aids } \\
\text { was found in the } \\
\text { intervention group in } \\
\text { the early postoperative } \\
\text { phase. }\end{array}$ \\
\hline $\begin{array}{l}\text { Tkachenko } \\
\text { Bril A, David } \\
\text { V, Scherer M, } \\
\text { Jagos H, Kafka } \\
\text { P, Sabo A. }{ }^{38}\end{array}$ & Austria & $\begin{array}{l}\text { Feasibility } \\
\text { study }\end{array}$ & $\begin{array}{c}\text { Three young male } \\
\text { subjects tested } \\
\text { REHABitation eShoe } \\
\text { load live-feedback } \\
\text { system. }\end{array}$ & $\begin{array}{c}\text { The novel live } \\
\text { feedback system } \\
\text { provides an } \\
\text { audible and haptic } \\
\text { biofeedback alarm } \\
\text { when a predefined } \\
\text { threshold is reached } \\
\text { by the pressure } \\
\text { sensors' data of a } \\
\text { pair of instrumented } \\
\text { insoles. }\end{array}$ & $\begin{array}{l}\text { The alarm } \\
\text { functionality works } \\
\text { in accordance with } \\
\text { the stipulations. The } \\
\text { biofeedback also } \\
\text { appears to have a } \\
\text { positive effect on the } \\
\text { number of steps under } \\
\text { the target weight. }\end{array}$ \\
\hline
\end{tabular}




\begin{tabular}{|c|c|c|c|c|c|}
\hline Trial & State & Design & Participants & Intervention & Results \\
\hline $\begin{array}{c}\text { Braun BJ, } \\
\text { Bushuven } \\
\text { E, Hell R, } \\
\text { Veith NT, } \\
\text { Buschbaum J, } \\
\text { Holstein JH, } \\
\text { Pohlemann } \\
\text { T. }{ }^{39}\end{array}$ & Germany & $\begin{array}{c}\text { Prospective } \\
\text { controlled } \\
\text { study. }\end{array}$ & $\begin{array}{l}\text { Ten patients with } \\
\text { ankle fractures. }\end{array}$ & $\begin{array}{l}\text { The patients' } \\
\text { activity, gait and load } \\
\text { characteristics were } \\
\text { recorded with the } \\
\text { OpenGo insole for up } \\
\text { to } 3 \text { months. }\end{array}$ & $\begin{array}{l}\text { The high performing } \\
\text { patients could } \\
\text { be identified via } \\
\text { biofeedback system } \\
\text { and influenced } \\
\text { towards optimal } \\
\text { healing conditions } \\
\text { early, while low } \\
\text { performing patients } \\
\text { are recognised and } \\
\text { missing healing } \\
\text { influences could be } \\
\text { corrected according to } \\
\text { patient condition. }\end{array}$ \\
\hline
\end{tabular}

\section{Discussion}

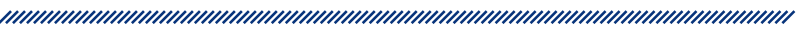

Biofeedback systems have been more effective than conventional bathroom scales in training patients to comply with weight-bearing limitations. ${ }^{1,5,7,10}$ Hersko et al. ${ }^{27}$ randomly divided patients $(\mathrm{N}=33)$ who had orthopaedic surgery into study group $(n=15)$ and control group $(n=18)$. First group were instructed of PWB by the biofeedback in-shoe device and second group was instructed with usage of scales. They completed 10 days of a rehabilitation protocol. A significant difference was found between the control group who used biofeedback systems for instruction of PWB and control group which were instructed with scales. ${ }^{27}$ Control subjects exceeded up to $60 \%$ of body weight beyond the permitted range. ${ }^{27}$ Tkachenko et al. ${ }^{32}$ identified that patient with hip fracture, who was using biofeedback in-shoe device in rehabilitation process, doubled the number of correctly loaded steps which affected on pace of patient recovery. The biofeedback system also has a positive effect on PWB performance of geriatric subjects while walking. ${ }^{27,32}$ The findings suggest that biofeedback inshoe devices seem to be a useful tool to obtain more precise insight of outpatients' activity and load to the injured limb during the healing process. ${ }^{25,34-39}$ Similar findings have been described in various reports. ${ }^{22-25,27-34}$

New technological advances in orthopaedics have created biofeedback devices designed to offer dynamic gait feedback to patients while walking. Commercially available biofeedback systems that are the most notable in current review are the F-Scan, PEDAR and SmartStep weight-monitoring systems. F-Scan has real-time plantar pressures, excellent for orthotics evals. ${ }^{15}$ The in-shoe advantages of F-Scan have been utilized by researchers who have conducted a series of useful clinical studies focused mainly on the evaluation of various therapeutic measures including footwear and in-shoe orthoses. ${ }^{11,15-}$ $19,23,25,33$ A study compared the F-scan, Medilogic and the Pedar and found that the F-scan had higher average errors, but a lower repeatability for contact area, especially at lower pressures. ${ }^{26}$ Pedar is sensitive pressure monitoring system excellent for research. ${ }^{11,15,22-24,31}$ Pedar insole system still measures uniform pressure more accurately and with greater repeatability than does the F-Scan system with new resistive ink insoles and with calibration via a bladder. The Pedar system also demonstrated lower variance across sensors, suggesting that sensor to sensor random errors were lower in the Pedar system. $22,24,25,33$ Reiff ${ }^{24}$ compared the current biofeedback devices regarding to criteria list (design, availability, functionality, weight, price, hysteresis), concluding that F-scan and Pedar are the best option for research and clinical use, have the best accuracy and validity but are too expensive and not affordable for public. A comparative study between the Pedar and F-Scan system showed the superiority of the Pedar system in both validity and reliability. ${ }^{24}$ These findings, generally, indicate that applications requiring the greatest accuracy and/or repeatability would be best performed with a Pedar system.

SmartStep, Soleforce, Sensistep and eShoe are more appropriate for monitoring of outpatient activity because of simplified design and operating system. Studies found out that the orthopaedic patients who were using SmartStep, Soleforce ${ }^{\circledast}$ or eShoe biofeedback systems are able 
to follow weight-bearing instructions better and had positive effect on the number of steps under the target weight. ${ }^{27,28,31-33}$ Furthermore, significant improvement in peak load and reduced use of walking aids was found in orthopaedic patients who used biofeedback in-shoe devices. ${ }^{37}$ In the validity study, the biofeedback system OpenGo science and system SmartStep provided valid feedback in the lower weight-bearing categories, and the biofeedback system SensiStep showed poor validity of feedback in all weight-bearing categories. ${ }^{31}$ Furthermore, SmartStep overall usability seemed only acceptable from the patient's perspective. ${ }^{29}$

Furthermore, relatively few studies have been designed to examine the use of biofeedback in orthopaedic patients. ${ }^{1,4,5,7-9,915-17,19,25,27,28,37,38}$ The findings here suggest biofeedback may be an effective tool with orthopaedic patients. With additional research biofeedback devices may very well become a part of the mainstay of clinical practice in orthopaedic partial weightbearing patients.

\section{Conclusion}

Biofeedback systems have been more effective than conventional bathroom scales in training patients to comply with weight-bearing limitations. New technological advances in orthopaedics have created biofeedback devices designed to offer dynamic gait feedback to patients while walking. Commercially available biofeedback systems that are the most notable in current review are the F-Scan, PEDAR and SmartStep weightmonitoring systems. Studies found out that the orthopaedic patients who were using biofeedback systems are able to follow weight-bearing instructions better and had positive effect on the number of steps under the target weight. The findings suggest biofeedback may be an effective tool with orthopaedic patients. With additional research biofeedback devices may very well become a part of the mainstay of clinical practice in orthopaedic partial weightbearing patients. The current review also has identified the need of development of new, less expensive in-shoe biofeedback device which will be appropriate for clinical use and monitoring of outpatient activities with prescribed PWB.

Plans are underway to develop less expensive biofeedback in-shoe device called ReStep, in collaboration with Croatian company FizioTech d.o.o Pula, intended for clinical use and patient home use.

\section{References}

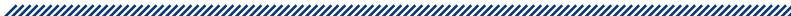

1. Hustedt JW, Blizzard DJ, Baumgaertner MR, Leslie MP, Grauer JN. Current advances in training orthopaedic patients to comply with partial weight-bearing instructions. Yale J Biol Med. 2012;85:119.

2. Hurkmans HL, Bussmann JB, Benda E. Validity and Interobserver Reliability of Visual Observation to Assess Partial Weight Bearing. Arch Phys Med Rehabil. 2009;90:309.

3. Malviya A, Richards J, Jones RK, Udwadia A, Doyle J. Reproducibilty of partial weight bearing. Injury. 2005;36:556.

4. Wirtz DC, Niethard FU. Etiology, diagnosis and therapy of aseptic hip prosthesis loosening--a status assessment. Z Orthop Ihre Grenzgeb. 1997;135(4):270-80.

5. Vasarhelyi A, Baumert T, Fritsch C, Hopfenmüller W, Gradl G, Mittlmeier T. Partial weight bearing after surgery for fractures of the lower extremity-is it achievable?. Gait Posture. 2006;23(1):99-105.

6. Gapsis JJ, Grabois M, Borrell RM, Menken SA, Kelly M. Limb load moniotr- evaluation of a sensory feedback device for controlled weight bearing. Arch Phys Med Rehabil. 1982;63:38.

7. Endicott D, Roemer R, Brooks S, Meisel H. Leg load warning system for the orthopaedically handicapped. Med Biol Eng. 1974;12(3):318-21.

8. Ebert JR, Ackland TR, Lloyd DG, Wood DJ. Accuracy of partial weight bearing after autologous chondrocyte implantation. Arch Phys Med Rehabil. 2008;89:1528-34.

9. Perren T, Matter P. Feedback-controlled weight bearing following osteosynthesis of the lower extremity. Swiss Surg. 1996;2:25.

10. Hurkmans HL, Bussmann JB, Benda E, Verhaar JA, Stam $\mathrm{HJ}$. Techniques for measuring weight bearing during standing and walking. Clin Biomech. 2003;18(7):576-89.

11. McPoil T, Cornwall M, Yamada W. A comparison of two inshoe plantar pressure measurement systems. Int J Low Extrem Wounds. 1995;2:95-103.

12. Smartstep. Andante Medical Devices Ltd. https://www. medgadget.com/2005/06/the_smartstep_g.html. Accessed Feb 11, 2020.

13. Sensistep. Evalan. http://www.sensistep.com/information-technical. Accessed Feb 11, 2020.

14. Schaff PS. An overview of foot pressure measurement systems. Clin Podiatr Med Surg 1993; 3: 403

15. Young CR. The F-Scan system of foot pressure analysis. Clin Podiatr Med Surg. 1993;3: 455-61

16. Corbett ML, Abramowitz AJ, Fowble CD et al. In-shoe plantar pressure measurement of the first metatarsophalangeal joint in asymptomatic patients. Foot Ankle. 1993; 14(9):520-4

17. Hayda R. Tremaine DM, Tremaine $K$ et al. Effect of metatarsal pads and their positioning: a quantitative assessment. FootAnkle 1994;10: 561 
18. Rose NE, Feiwell LA, Cracchiolo A. A method for measuring foot pressures using a high resolution, computerised insole sensor: The effect of heel wedges on plantar pressure distribution and centre of force. Foot Ankle 1992; 13(5): 263-70

19. Stephen A, Rinoie C. Effect of custom orthotics on plantar pressure distribution in the pronated diabetic foot. J Foot Ankle Surg 1994; 33(6): 598-604

20. Tan AM, Fuss FK, Weizman Y, Troynikov O. Development of a smart insole for medical and sports purposes. Procedia Eng. 2015;112:152-6.

21. Razak A, Hadi A, Zayegh A, Begg RK, Wahab Y. Foot plantar pressure measurement system: A review. Sensors. 2012;12:884-912.

22. Woodburn J, Helliwell PS. Observations on the F-Scan in-shoe pressure measuring system. Clin Biomech. 1996;11:301-4

23. Price C, Parker D, Nester C. Validity and repeatability of three in-shoe pressure measurement systems. Gait Posture. 2016;46:69-74.

24. Reiff AL. Different in-shoe devices for partial weight bearing (Bacc Thesis), Groningen, Netherlands: Faculty of science and engineering; 2016.

25. Hurkmans HL, Bussmann JB, Benda E, Haisma JA, Verhaar JA, Stam HJ. Predictors of partial weight-bearing performance after total hip arthroplasty. J Rehabil Med. 2010;42(1):42-8.

26. Gray FB, Gray C, McClanahan JW. Assessing the accuracy of partial weight-bearing instruction. Am J Orthop. 1998;27:558-60.

27. Hershko E, Tauber C, Carmeli E. Biofeedback versus physiotherapy in patients with partial weight-bearing. Am J Orthop. 2008;37:92-6.

28. Isakov E. Gait rehabilitation: a new biofeedback device for monitoring and enhancing weight-bearing over the affected lower limb. Eura Medicophys. 2007;43:21.

29. Lieshout R, Pisters MF, Vanwanseele B, de Bie RA, Wouters EJ, Stukstette MJ. Biofeedback in partial weight bearing: usability of two different devices from a patient's and physical therapist's perspective. PloS one. 2016;11(10).
30. Döbele S, Deininger C, Sandmann GH, Schmitt A, Freude T, Stöckle U, Lucke M. New Method for Monitoring Partial Weight Bearing (PWB) of Outpatients with an Independent Insole Sensor System. Acta Chir Orthop Traumatol Cech. 2016;83(2):88-93.

31. Van Lieshout R, Stukstette MJ, De Bie RA, Vanwanseele B, Pisters MF. Biofeedback in Partial Weight Bearing: Validity of 3 Different Devices. J Orthop Sports Phys Ther. 2016;46:993-1001.

32. Tkachenko-Bril Al, Jagoš H, David V, Pils K, Gaudernak J, Rafolt D. Proof of Concept of a Partial Weight-Bearing Supporting Real-Time Feedback System. Stud Health Technol Inform. 2018;248:286-92.

33. Zhang DT, Goral DC, Fragomen AT, Rozbruch SR. Soleforce ${ }^{\circledR}$ : A Novel Biofeedback Device that Improves Patient Compliance with Lower Extremity Partial WeightBearing. World J Surg Surgical Res. 2019;2;1181.

34. Le AY. Pilot investigation of effectiveness of real-time feedback-assisted partial weight bearing (MSc. Thesis), Utah, USA: The University of Utah; 2015.

35. Saito M, Nakajima K, Takano C, Ohta Y, Sugimoto C, Ezoe R, Sasaki K, Hosaka H, Ifukube T, Ino S, Yamashita K. An in-shoe device to measure plantar pressure during daily human activity. Med Eng Phys. 2011;33:638-45.

36. Morris SJ. A shoe-integrated sensor system for wireless gait analysis and real-time therapeutic feedback (PhD Thesis), Massachusetts, USA: Massachusetts Institute of Technology; 2004.

37. Raaben M, Vogely HC, Blokhuis TJ. Real-time visual biofeedback to improve therapy compliance after total hip arthroplasty: A pilot randomized controlled trial. Gait Posture. 2018;61:306-10.

38. Tkachenko Bril A, David V, Scherer M, Jagos H, Kafka P, Sabo A. Development of a wearable live-feedback system to support partial weight-bearing while recovering from lower extremity injuries. Procedia Eng. 2016;147:157-62.

39. Braun BJ, Veith NT, Hell R, Döbele S, Roland M, Rollmann $M$, Holstein J, Pohlemann T. Validation and reliability testing of a new, fully integrated gait analysis insole. J Foot Ankle Res. 2015;8:54. 


\section{DOSTUPNOST I UPORABA RAZLIČITIH BIOFEEDBACK UREĐAJA}

\section{ZA DOZIRANO OPTEREĆENJE}

1 Petra Josipović

1 Medicinski fakultet Ljubljana

Fiziotech d.o.o, (R\&D) department

\section{Sažetak}

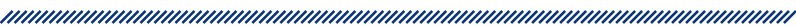

Uvod: Fizioterapeuti primjenjuju različite metode kao što su taktilna sprega, uporaba vage i uporaba uređaja za biofeedback u učenju pacijenata pravilnom doziranom opterećenju nakon operacijskih zahvata. Učenje ortopedskih pacijenata pravilnom doziranom opterećenju ekstremiteta s pomoću uređaja za biofeedback objektivnija je i učinkovitija metoda fizioterapijskog tretmana od metode primjene vage.

Cilj: Sistematični pregledni članak fokusirat će se na problematiku dostupnosti i kliničke uporabe uređaja za biofeedback kod pacijenata kojima su fizioterapeut i liječnik propisali dozirano opterećenje.

Metode: U pretrazi su upotrijebljene sljedeće ključne riječi: dozirano opterećenje, uređaj za povratnu spregu u cipeli, uređaji za biofeedback, operacija. Pretraga je provedena u pet bibliografskih baza podataka (PubMed, PEDro, Google Scholar, ClinicalTrials.gov i ScienceDirect).

Rezultati: U pretrazi literature primijenjena je strategija filtracije izvora prema određenim parametrima. U obradi podataka primijenjen je kvalitativni analitični pristup. Za konačnu analizu odabrano je 15 prikladnih izvora.
Zaključak: Sustavi za biofeedback učinkovitiji su od konvencionalnih vaga u podučavanju pacijenata pravilnom doziranom opterećenju oštećenih ekstremiteta. Daljnjim znanstvenim, randomiziranim i kliničkim istraživanjima, sustavi za biofeedback mogu postati važan dio kliničke prakse u tretmanu ortopedskih pacijenata s propisanim doziranim opterećenjem.

Ključne riječi: dozirano opterećenje, biofeedback uređaji, postoperativna rehabilitacija 